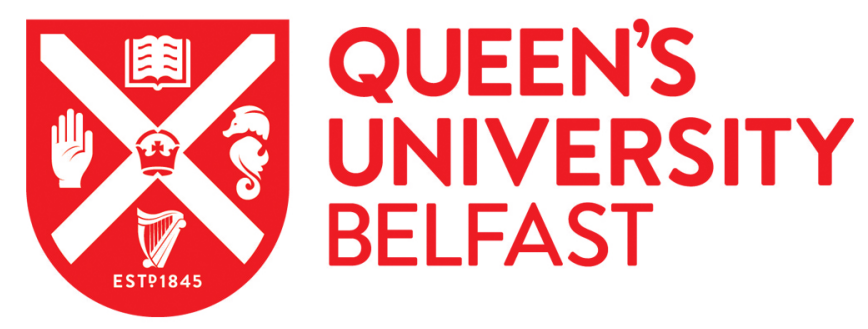

\title{
"Tell Them that My Dayly Thoughts are with Them as Though I was Amidst Them All": Friendship among Property-Owning Free People of Color in Nineteenth-Century Natchez, Mississippi
}

Ribianszky, N. (2017). "Tell Them that My Dayly Thoughts are with Them as Though I was Amidst Them All": Friendship among Property-Owning Free People of Color in Nineteenth-Century Natchez, Mississippi. Journal of Social History, 50(4), 701-719. https://doi.org/10.1093/jsh/shw092

Published in:

Journal of Social History

Document Version:

Peer reviewed version

Queen's University Belfast - Research Portal:

Link to publication record in Queen's University Belfast Research Portal

\section{Publisher rights}

Copyright (C) 2017 Oxford University Press. This work is made available online in accordance with the publisher's policies. Please refer to any applicable terms of use of the publisher.

\section{General rights}

Copyright for the publications made accessible via the Queen's University Belfast Research Portal is retained by the author(s) and / or other copyright owners and it is a condition of accessing these publications that users recognise and abide by the legal requirements associated with these rights.

Take down policy

The Research Portal is Queen's institutional repository that provides access to Queen's research output. Every effort has been made to ensure that content in the Research Portal does not infringe any person's rights, or applicable UK laws. If you discover content in the

Research Portal that you believe breaches copyright or violates any law, please contact openaccess@qub.ac.uk. 


\title{
"'Tell Them that My Dayly Thoughts are with Them as Though I was Amidst Them All': Friendship among Property-Owning Free People of Color in Nineteenth-Century Natchez, Mississippi ${ }^{1}$
}

\begin{abstract}
There is a considerable body of work about friendships between enslaved African Americans and the rewards that strong emotional ties conferred upon men and women living in bondage. However, much less has been paid to the bonds of friendship between free people of color, the tangible benefits these relationships provided, as well as their effect on the psychological wellbeing of men, women, and children. This article examines practices of friendship among property-owning free people of color in Natchez, Mississippi in the nineteenth century. It argues that free blacks formed friendships for the usual reasons of providing companionship and emotional support. Further, though, property-holding free men and women of color had to be particularly strategic in their choices of friends. They often limited their circles to other free people - family members especially — and to key white individuals, because friendship could be the difference between enslavement and freedom and the maintenance of their property in a society that continued to constrict the liberties of free blacks up to the Civil War.
\end{abstract}

When seventeen-year-old Octavia Miller of New Orleans declared in a letter to her aunt, free woman of color Ann Johnson, that, "you and grandmother is the only friends I have," she most likely was not speaking figuratively. ${ }^{2}$ In the nineteenth century up to the Civil War, property-owning free people of color living in the town of Natchez, Mississippi made up a tightly-knit community that maintained a small but visible presence in one of the wealthiest slave societies in the United States. In 1860, Mississippi had one of the largest enslaved populations in the U.S. at 436,631, but only 775 free people of color, one of the smallest populations of all southern states. Natchez distinguished itself within Mississippi for having the largest community of free people of color - the number, though, was a mere 225 free people of color compared to 14,292 enslaved African Americans in surrounding Adams County. The number of property owning free blacks was even smaller. A largely biracial population, they occupied a tenuous position: technically not enslaved but lacking white privilege. They grappled with a limited liberty that restricted them in multiple arenas, including occupations, education, and voting rights. Additionally, they faced a constant threat of deportation from the state or re-enslavement 
for any number of offenses. Free black people by necessity had to vigilantly maintain and nurture close bonds of friendship, within and outside of their families, as a protection against the restrictions of their local environment. Friendship, often deepest between family members, as in the case of Miller and her female relatives, was the glue that knit free people of color together into local communities of trust within Natchez and connected them to a larger diaspora outside of "the City on the Bluff” via the Mississippi River. ${ }^{3}$

The literature on friendship among people of African descent is growing but the great bulk of the scholarship overwhelmingly focuses on the enslaved. Starting in the 1970s, historians produced a plethora of slave community studies that examined the deep emotional connections between bondspeople. Monographs like Eugene Genovese's Roll, Jordan, Roll and John Blassingame's The Slave Community stressed the critical role friendship and kinship played in lending stability, comfort, and support to individuals whose lives were often shattered by the breakup of families, violence, and hard labor. It was not until the 1980s, however, that historians began employing gender as a tool of analysis to examine relationships among the enslaved. In her groundbreaking study of enslaved women, Deborah Gray White highlighted how deep bonds of friendship sustained enslaved women, providing them with support that often surpassed what they received from relationships with men. More recently, historians of masculinity have interrogated homosocial relationships between enslaved men and revealed them to be equally indispensable. The bonds of friendship that enslaved women and men forged gave them the psychological tools to withstand the dehumanizing aspects of enslavement. ${ }^{4}$

While scholarship dealing with friendship among the enslaved makes critical interventions, it does not map perfectly the unique experiences and circumstances of free people of color. There was certainly overlap between the enslaved and free blacks since many free 
blacks in Natchez had been born into slavery and later were manumitted, often leaving behind family members and friends who remained enslaved. Because of Mississippi's stringent manumission laws, free blacks frequently owned their own loved ones, including spouses, children, and siblings. Thus, they had deep and enduring friendships with those who were enslaved. However, there were a number of property-owning free people of color in Natchez who owned slaves for economic purposes. In fact, most of the free people discussed in this article belonged to slave owning families. ${ }^{5}$

This essay argues that practices of friendship among property-owning free black people in Natchez were vital support structures. Friendships provided companionship and emotional sustenance within this small community. Against the backdrop of the harsh realities of life in this racist, slave-based town, free men and women of color strategically formed and maintained friendships to protect their children and families. It was often safest for individuals to concentrate their closest friendships within the community and especially within family networks, to insulate themselves as much as possible within their "middle" status between slavery and the full freedom conferred by whiteness. By building these strong bonds, free people of color and their allies vouched for each other in court, supported their friends' businesses, celebrated together, and worshipped together. They also looked out for each other's children by providing educational opportunities, apprenticeships, and supervision. ${ }^{6}$

Circles of amity often included local whites and free people of color expended considerable energy to sustain these valuable relationships. Friendship between free blacks and white people was a multi-faceted phenomenon with many complications in a racialized society. Because the law codified racial differences that prevented whites and people of color from engaging on equal social footing, the development of genuine friendships was hindered and often 
outright stymied. When a free person of color applied the word "friend" to describe a local white person, the term often referred to someone who was closer to a patron than a companion connected by strong emotional ties. White friends were frequently people with whom free blacks shared commercial interests and upon whom they depended for legal and economic reasons, rather than for purely emotional and heartfelt ones. However, there were some notable and genuine interracial friendships that existed in Natchez. ${ }^{7}$

Friendship sometimes made the difference between enslavement and freedom. The state of freedom itself for people of African descent in North America prior to the abolition of slavery was not fixed, static, or monolithic. Free people of color were susceptible to re-enslavement for a barrage of offenses. Freedom, then, was not always a permanent state, but contingent and marked with fluidity — a tenuous and unstable purgatory that existed in various degrees between the poles of enslavement and freedom. Considering just how much was at stake, free blacks had to exercise particular care in choosing whom to trust and how much to reveal about personal, legal, and financial matters. In some cases, indiscretions with the wrong people resulted in severe consequences. $^{8}$

$* * * * * * * * * * * *$

A careful examination of the writings left behind by Ann Battles Johnson, William Johnson, and their family illustrates the tight-knit nature of family and friendships in free communities of color like Natchez. ${ }^{9}$ William's mother, Amy, was born a slave in approximately 1784. When she was in her early 20s, she gave birth to a daughter, Adelia, and to her son, William, three years later. Both children were fathered by Amy’s owner, William Johnson. In 1814, Amy and the elder William Johnson traveled across the Mississippi River from Natchez to Concordia Parish, Louisiana where he manumitted her. Her children remained enslaved until 
their father manumitted them, too, when they were 13 and 11, respectively. In the years following their transition to freedom, Amy peddled goods to support herself and her children. By the 1830s, both of Amy's children, Adelia and William, were beginning families of their own. Adelia married James Miller, a young free barber of color who had migrated in the 1820s from Philadelphia, Pennsylvania, to Natchez. The couple soon departed for New Orleans to seek better opportunities, but not before Miller trained his brother-in-law, William, in the lucrative profession of barbering and sold him his popular business. ${ }^{10}$

Like his sister, William soon began his own family in the 1830s. He met Ann Battles, a local free woman of color, and the pair embarked on a three-year courtship before they finally married in 1835 . The couple was part of a tiny propertied class of free blacks in Natchez. In a relatively short period, they acquired a home in town, three barbershops, a plantation, and a money-lending business (among other ventures). They also had ten children and owned more than thirty enslaved men and women at various times prior to the Civil War. James and Adelia Miller occupied a similar socioeconomic niche and had nine children. The families, despite being separated by a few hundred miles by river travel on the Mississippi, maintained close contact with each other through frequent communications, visits, and the exchange of gifts and goods from one town to the other. ${ }^{11}$

In light of the uncertain terrain upon which free people of color tread, friendships within families were the safest bets. Like free people of color in other southern cities, certain propertied families within Natchez practiced endogamous marriages within their small social circle. Prosperous families like the Johnson, Millers, Barlands, Fitzgeralds, McCarys, and Hoggatts thus consolidated friendships through the marriages of members of their families. Within these friendly family circles, members often held property in common, educated one another's 
children, and visited each other frequently. ${ }^{12}$ Johnson's recollections elucidate the mix of people - mainly free people of color - that his family entertained. On one occasion, he described a "Good many ladies at our house last night, old Mrs. Brustee, old Miss F. and young Miss F., Mrs Amie \& two daughters, Mis Henrietta, some other Miss of Jerman extraction, Mr Brustee and all our own children [.] They kept up the sport until 11 Oclock." ${ }^{13}$ The Amies, the Brustees, and the Millers were all former Natchezians who had relocated to New Orleans. They periodically returned to Natchez and visited with the Johnson family, entertaining themselves by going on walks and carriage rides around town and out to the countryside to the Johnsons' plantation, on picnics, and other outings. ${ }^{14}$

Free women of color during the early to mid-nineteenth century, especially those from propertied families like Ann Johnson and Adelia Miller, found shelter to some degree within their households because of their family's wealth and did not occupy the public sphere as openly as their male counterparts. Many free black women found it challenging to live up to the racialized expectations of the "cult of true womanhood," which with its emphasis on purity, piety, submissiveness, and domesticity, represented the dominant gender ideology for middle to upper class white women in the antebellum era. Although propertied free women of color aspired to these ideals, and particularly, domestic work within the home, most were forced to balance household labor and paid work. Free women of color, like men, were expected to earn money for the family as well as run the household effectively as wives and mothers. However, women of property, who often owned slaves, were able to exploit slave labor and send them out into the marketplace to sell produce or sewn goods that they produced in the home. Propertied women, then, were more comfortably situated to enjoy a rich female world organized around the rituals of puberty, marriage, pregnancy and childbirth, and work within the households. In this space, 
the line between kin and friendship blurred and women counted family members among their dearest friends. ${ }^{15}$ The letters of the Johnson and Miller women demonstrate how profound these ties were as they discussed childbirth, work, local gossip, and other matters of deep interest. ${ }^{16}$ Unmarried and working class free women of color or those who had little or no property did not always have the luxury of relying as heavily upon kin to supply friendships and often had to reach outside the household to do so. Although free men of color also built close ties to relatives, for women — whose public lives were more constricted - the insular walls of kinship proved a comforting reality.

An important function of friendship among free black friends was to mediate domestic conflicts. This was certainly the case for the Johnsons and their friends, the Brusties, who remained close even after the Brusties moved to New Orleans. In fact, two generations of Brustie men, Gabriel and his son Gabriel, Jr., required the intervention of Ann and William during troubled times with their wives. The Johnsons had first refereed tensions between Gabriel, Sr. and Marie when he was reputedly "treating his wife very badly." 17 Fifteen years later, the younger Gabriel Brustie wrote to Ann when he, too, experienced marital stress with his wife and needed assistance. He and his wife, Victoire, were temporarily separated and she refused to return to their home in New Orleans. He appealed to Ann to convince his wife to meet with him because as he pointed out "conversing together privatly [sic] and writing letters makes a great differents [sic] between husban[d] and wife."18 The depth of his respect and friendship with Ann is clear in the praise he heaped upon her when he acknowledged her for "all that you have done and still will do in reconciliating [sic] me and my wife. And I shall never in this world forget your kind feelings in our little Difficulties wich [sic] I hope is almost come to an end."19 
A poignant aspect of friendship between free men and women of color involved supporting one another as parents and fostering positive interactions with each other's children. William Johnson frequently made mention of taking his own children along with their cousins and the daughters and sons of his friends on walks and carriage rides, trips to the circus, and excursions to the local pond to race toy boats. ${ }^{20}$ In one telling series of diary entries, Johnson recalls his friends' support during the protracted illness of his son, Richard, who suffered from fever and seizures for over two weeks. Throughout that time, his close friend, Robert McCary, another free man of color, demonstrated concern by holding a vigil by Richard's bedside for several nights. In one entry, Johnson related that,

My Little Richard very Low. Poor Little Fellow, He suffers so much-McCary and Mrs Gibson Sat up with him to night all night—He was very ill Just before Day. His Cough was very Troubled about it ie [sic] the Child could get no rest. Oh no One Knows how much the Poor Little Fellow Suffers at this very time-I got moore [sic] sleep to night [sic] than I have had any One night sinse [sic] it was Taken. ${ }^{21}$

Several friends of the Johnson family came during the period of Richard's illness and sat through the night in shifts, allowing the weary parents sleep as they nursed their child to health. Besides providing an invaluable physical presence by remaining awake to monitor Richard, these family friends provided emotional support and staved off feelings of isolation as they went through this frightening period. Although affluent free people of color like the Johnsons and McCarys could afford to have doctors visit their children in their sickbeds and dispense medical advice and treatment, friends offered invaluable comfort through long hours of worry. ${ }^{22}$

Friends like McCary who demonstrated their concern and loyalty by sitting at the bedsides of loved ones during times of sickness were not unusual. Often, they also selflessly provided comfort to their beloved friends on their deathbeds. As Johnson noted in his diary, "Miss Catherine Evans is not hardley [sic] Expected to Live the night out—She is very Sik [sic]. 
They Sent the Carriage for Mrs Battles [Johnson's mother-in-law] to night and she went out Amediately [sic] to see Her and when she got Out she found her speechless and dyeing [sic] and the poor Lady Died at 11 Oclock to night. [A] Good many of her friends was present at her death. ${ }^{" 23}$ In another case, Johnson's mother, Amy visited Kitty McCary, Robert McCary's sister, a propertied woman of color, on her deathbed. Peter Lawrence, a white man, had severely beaten Kitty and she likely died from related complications. Johnson noted that, "Peter Lawrence got clear of the charge of whiping [sic] Kity McCary—-there was no Bill found against him.” Describing this unjust turn of events as "Rascally. Rascally," Johnson clearly conveyed his frustration and disgust that the law failed to vindicate and protect free people of color-even those property holders like Kitty and himself -from acts of white racial violence. Free people of color were uniquely qualified to support their friends after violent events like this one. ${ }^{24}$

The practice of apprenticeship created bonds of patronage and protection between free blacks and functioned as a potential birthplace of free black friendships. Because they were embedded in the household, free black apprentices met and socialized with extended family members and became linked into a nexus of friendships. William Johnson apprenticed at least seven free black boys over the course of sixteen years. The boys ranged between the ages of ten and eighteen, the age at which their apprenticeships ended. Johnson provided them with basic education, skills training, food, clothing, and housing. He also served as a surrogate father figure to them and disciplined them physically for minor infractions as he noted numerous times in his diary. For example, in 1836, Johnson remarked that he "had to whip Little Bill [Hayden] \& John for fighting in the shop." ${ }^{25}$ In spite of the rigorous punishments they often met at Johnson's hands, the boys trained for their vocation, received educations, and entertained themselves in their free time by attending circuses, parties, and the theatre. At the conclusion of their 
apprenticeships, they were free to start businesses of their own, find employment with another barber, or continue to contract with Johnson in one of his three shops. Indeed, these types of relationships often led to the creation of family ties as in the case of one of Johnson's apprentices, Jefferson Hoggatt, who later married Johnson's niece, Emma Miller. Altogether, five Hoggatt brothers, apprenticed with Johnson and, at different times, they each lived and worked in the Johnson household, learned their lessons alongside the family's children and frequently went on outings with the family. In Jefferson's (or Jeff, as the family called him) case, he was sometimes sent on errands to New Orleans to convey goods or news to the Miller family, which helped him establish ties to Johnson's kin. ${ }^{26}$

Free black men like Johnson helped facilitate the apprenticeships of other free boys and girls of color with appropriate people. Although there is no evidence of Johnson apprenticing girls in his shop, he was instrumental in securing the indentures of two young girls, Emeline and Missouri Hoggatt, Jefferson's sisters. The Hoggatts were the children of Wilford Hoggatt, a white planter and his enslaved woman, Phoebe. Hoggatt freed Phoebe and their seven children in 1840 and left them substantial property. Johnson attempted to indenture them to learn to sew with a local woman, Ms. Dowell, who owned a store in town. However, he decided it was not a suitable placement because "the old Lady was too Foul mouthed Intirely [sic]. It would not do." ${ }^{27}$ As Johnson's assessment makes clear, it was vital to locate a place of apprenticeship for young free black children that was safe and respectable. Only then would they benefit from their indenture and not be at risk of abuse. As this case demonstrates, free people of color were acutely sensitive to these concerns and committed to safeguarding their friends' interests.

When free black men and women forged friendly apprenticeship agreements with one another, it further protected their children against exploitation. Typically, the Orphan's Court in 
Natchez handled the apprenticeship of indigent children as well as free children of color. Poor free women of color often had to bind their children out as apprentices until they reached adulthood. The laws of Mississippi gave local trustees of the poor power to assess "all the poor free negro or mulatto children... whose parents, if they have any, they shall judge incapable of supporting and bringing them up in honest ways." ${ }^{28}$ This subjective language could justify poor children being taken from their parents to labor for white people for free. Further, it gave the county and probate courts the "power to order the said overseers or trustees to bind out all such free negro or mulatto children, apprentices to such person or persons whom the court [emphasis mine] shall approve, until the age of twenty-one years, if a male, or eighteen years if a female." This took control away from the parent to locate a person they trusted to take in their child for a long time period. Finally, the courts were under no obligation to make provisions for the education of free black apprentices as was standard in apprenticeships set up for whites. ${ }^{29}$ Free people of color like Johnson and Robert McCary who intervened and actively served as agents in securing apprenticeships for their friends' children ensured some modicum of control over their safe and profitable placements.

Bonds of religion also sustained friendships in the free black community. For hundreds of years in the Lower Mississippi Valley, as a result of colonization by the Spanish and French, similar to practices in parts of Latin America, having infants baptized and securing godparents was not only a means of initiating children into spiritual practices; it could also mean a strategic social alliance with powerful advocates, such as ex-owners or other influential whites. Affiliation with a religious organization, particularly the Catholic Church, provided free blacks with access to a number of services including burials and charitable aid. It plugged them into a larger network that reached beyond the local free black population. For instance, free people of color 
from Natchez would often have their children baptized and recorded as free in the St. Louis Cathedral in New Orleans, as an additional measure of security. ${ }^{30}$

In the household of Felicite Gireaudeau, religion enabled the construction of spiritual friendships that had a ripple effect in the wider community. Gireaudeau, a wealthy and influential French-speaking free woman of color originally from New Orleans who passed as white in Natchez was a devout Catholic who facilitated the baptism of certain enslaved people in her household and later, their manumission. Some of her former slaves, such as Nancy Gireaudeau (who was manumitted by Felicite in 1830) and her daughters Sophia, Roselle, and Frances remained entwined in mutual obligations to Felicite. The formerly enslaved women expanded on the linkage between religion and freedom by serving as baptism sponsors for other enslaved people and having Felicite and her family members baptize their own free children of color. These types of ties often connected people long after the claims of ownership expired, as in the case of Nancy and her daughters, who remained joined with Felicite in ushering in new communicants to Catholicism for over 20 years following their emancipation. ${ }^{31}$

Religious camaraderie linked many other free men and women and strengthened their friendship through the profession and practice of faith. One free woman and former resident of Natchez, Phoebe Smith, maintained connections with family and friends through their common spiritual pursuit. In a letter to her son she encouraged him to find salvation and make preparations for the imminent judgment of his soul. She then continued with assurances to Ann Johnson, who was the likely employer of her son and whose husband William had recently been murdered. To Ann, Phoebe wrote,

I am in hopes that the Lord will pertect [protect] you and your little children and I am in hopes that he will pertect [protect] all in the holer [holler] of his pertected [protected] hands. And tell sister Nancy Hilds that I am still marching toward the promise Land and I[']m in hopes to meet you in the promised Land. And also I still 
remains your kind and affectionate sister until death."32

Thus, religion bound free people of color together and helped mitigate some of the everyday stress wrought by the oppression directed against them. Like many whites, free people of color facing the death of friends and loved ones undoubtedly found some small comfort in the belief that they would be reunited in heaven.

Given the precariousness of their status as free in a society that viewed people of African descent as enslaved, free people of color needed to forge patron-client relationships with local whites. Often, these whites were former owners who intimately knew the person's character and from the moment of their manumission —indeed, as a condition of it — willingly supported him or her. The emancipating owner Thomas Nichols of Kentucky claimed that he would, "warrant and forever defend his [slave Aaron's] freedom from the claim or claims of all and every Person or Persons whatsoever." 33 Maintaining friendly relations with former owners enabled free blacks to depend on them in times of need, as well as to rely on them to vouch for their good names, and to patronize their businesses.

Although these patron/client relationships could be based on warm, mutual feelings, the racial inequality that characterized them problematized them. Relationships between free people of color and whites that truly transcended barriers and resembled authentic friendships were less common than those between free people of color because of the prevailing norms of white supremacy. However, there were exceptions such as the friendship that existed between Adam Bingaman and the family of William and Ann Johnson. Bingaman came from an old and influential Natchez family and was a wealthy planter. A Harvard graduate, he also had an illustrious political career, serving as the Speaker of the Mississippi state legislature from 183436, and then as president of the U.S. Senate from 1838-1840. 
Bingaman vocally supported the free black community during the period that William Johnson termed "the Inquisition" in 1841. Mississippi's laws dating back to 1820 required that free black people proved their freedom, paid a fee, and registered with local courts. In times of hysteria following slave uprisings like Nat Turner's in 1831, there were crackdowns to ensure that individuals were properly licensed. ${ }^{34}$ During the "Inquisition," reports of a nearby slave uprising inspired panic among legislators and the general public, with profoundly negative consequences for free people of color. A vigilance committee formed in Natchez, an action that whites in Vicksburg and Holly Springs soon imitated. This committee, along with the editors of local papers, called for the removal of all unlicensed free people of color from Natchez and even revoked the licenses of some. ${ }^{35}$ One Mississippi Free Trader article encouraged residents " "to strike a severe blow against the practices of the rogue, the incendiary, and the abolitionist,' by regulating slave conduct and by 'the immediate removal of every free Negro, who has intruded upon our society." " ${ }^{36}$ Johnson chronicles the frenzied activities of free black people asking whites to sign petitions that would enable them to stay in town. Some men, women, and children were unlucky in this pursuit and were deported from the state. In spite of the hysteria, Bingaman continued to advocate for local free people of color. He acted contrary to the guiding principles of the Mississippi Colonization Society—among whose leading members were some of Bingaman's family and friends — which sought to remove free blacks to Africa, and he remained aloof from their activities in ideology and practice. ${ }^{37}$

Bingaman, like some other white men in Natchez, was also in an openly acknowledged relationship with his former bondwoman, Mary Ellen Williams, whom he manumitted and with whom he had several children. In addition to openly acknowledging his interracial family, Bingaman was a patron of William Johnson's barbershop as well as a personal family friend. He 
and Johnson had a mutual interest in horseracing and frequently discussed this passion and attended races. He served as administrator of the family's estate after Johnson's murder in 1851 and saw to the care of one of William and Amy's sons, who had to be institutionalized due to mental illness. In a letter to Johnson's daughter, Anna, who assumed the position of family head after both parents passed, Bingaman assured her that, "I have not seen William lately. But I know he is well as I required to the Keeper of the Asylum to let me know when he was unwell. ${ }^{\text {"38 }} \mathrm{He}$ remained connected to the family in friendship after he and his family relocated to New Orleans. In the years leading up to the Civil War and afterwards, Bingaman experienced significant financial losses and ended many of his associations with the Natchez elite. He sacrificed his former social standing to live openly with his family. ${ }^{39}$

Free people of color often appointed men like Bingaman and other trustworthy white men to serve in administrative roles on their behalf. For example, they named whites as managers or administrators of their estates so that after their deaths, the white men could hold their estates in trust for their children and make arrangements for their educations, apprenticeships, marriages, and overall well-being. A white friend was a powerful ally, sharing his or her racial privilege and capital with free black friends.

Similarly, free parents of color deliberately maintained friendships with trusted white men in order to unite their daughters in matrimony with them, no doubt as an added protection in a society that was largely hostile to free blacks. Thus, Harriet Johnson, who was romantically linked herself to two white partners, may have likewise encouraged both of her daughters to marry white men. ${ }^{40}$ White fathers in particular and some free fathers of color also sought to marry their daughters of color to white men. The four daughters of white William Barland and his "colored wife Lisey [Elizabeth]" all married white men as did the two daughters of George 
Winn, a free black man who left his two daughters and son over 1,200 acres and other property. ${ }^{41}$ This was not a strategy unique to Natchez. In fact, in an 1856 Mississippi Supreme Court case that originated from another county, a white father had left instructions for his executor to "have said girl Harriet [his daughter by his enslaved woman, Fanny] brought up as a free woman, and ultimately to be given in marriage to a white man." If this condition was met, Harriet would then inherit her father's property. ${ }^{42}$ This tactic, in fact, was particularly important for families whose daughters were bequeathed real or personal estate. The idea was that there would be far less chance of a free black daughter losing her property through fraud or legal technicalities if a white man, her husband, controlled it. ${ }^{43}$

Although the benefits of friendship were indeed numerous, the legal vulnerability of free people of color opened them up for abuse, even by professed friends. Since freedom and property were often at risk for free people of color, they needed to choose their friends wisely. This was true at all times, but especially during moments of extreme hostility, such as in the 1830s and 1840s when white Natchez citizens "purged" the community of free people of color. In the face of these attacks, free men and women of color struggled to find the strongest possible allies in whom to place their trust.

The case of Fanny Leiper, and Malvina Huffman, two free women of color, who were neighbors, illustrates the dangers of revealing too much sensitive information to a supposed friend. ${ }^{44}$ In 1847 Leiper initiated a suit in Mississippi’s Southern District Chancery Court in Natchez against Huffmann as well as the white men Oliver Bemiss, Joseph Winscott, and Malvina's agent James Walsh for defrauding her of her property by false means. Several of the witnesses who testified in the case stated that they often noticed the women visiting one another, presumably as friends and not mere acquaintances. However, Huffman took advantage of their 
friendship and used information about Leiper to her own gain in 1845. Following what William Johnson called the "Inquisition" in 1841 when there was a crackdown on free people of color in Natchez, Leiper moved to Cincinnati, Ohio, and hired an agent, Samuel R. Hammet, to rent out her property and collect the monthly rent of eight dollars for her. It was not long after her departure that Huffman recognized the opportunity to capitalize on Leiper's absence in Natchez. In the latter part of 1846, Leiper's tenant, Maria Ann Cooper, moved out and returned the keys to Hammett. At this time, Huffman's white lover, Oliver Bemiss, disclosed to Hammet that he had purchased the property for Huffman from Joseph Winscott, Leiper's former lover, of New Orleans for $\$ 100$ or $\$ 125$. Later, Huffman sent a "colored girl," possibly her slave, and requested Hammet send the key to her. Hammett, not realizing the transaction had occurred without Leiper's permission, surrendered the keys to Huffman, who subsequently took possession of the house. ${ }^{45}$

When Leiper initiated the 1847 petition against Huffman and her three associates, she charged that Huffman knew Winscott's name was on the deed and falsely informed him that Leiper was in actuality a slave who could not hold property. Huffman then convinced Winscott that Leiper had fled Natchez, that the property was going to ruin, and that he should sell it to her. He did. The result was a legal drama that lasted over four years. The local court ruled that Leiper was not entitled to any relief and ordered the case dismissed at her expense. Dissatisfied with this verdict, Leiper appealed to the Mississippi High Court of Error and Appeals to settle the question of whether or not she was a free woman who could hold property because she met the Court's standard of someone with "absolute Control of her own time and person, without being subject to the control of anyone else." ${ }^{46}$ She eventually won the case but nevertheless lost the house and lot due to her untenable position as a free black woman who had been forced to leave 
Natchez years earlier for Cincinnati. Controlling the property from a distance proved too challenging and Huffman ultimately preserved the house and lot for herself.

This case lays bare some essential reasons why choosing reliable friends and allies was of paramount importance to free people of color. As Leiper's experience demonstrates, freedom and the ownership of property buttressed one another and the struggle to maintain both could be challenging for free people of color. In this case, it pit one-time friends of the same social class, and friendship network, against one another. Leiper's decision to put all of her property into the hands of a white trustee and to share sensitive information with an ostensibly close friend was a risky gamble.

William Johnson's friendship with his neighbor Baylor Winn, like that of Leiper and Huffman, reveals how threatening the prospect of losing property and community standing was for free blacks - it could even have fatal consequences. Johnson and Winn had a long history of friendly relations with one another dating back almost two decades. The two men periodically visited one another's homes, hunted together, exchanged small gifts, and discussed business and family matters. Their friendship rapidly deteriorated, however, following a property boundary dispute in the late 1840s. Indeed, as Johnson intimated in his diary, 'old man Winn is an overbearring [sic] old Color[e]d Gentleman, and it will be found out So before Long if he fools much with me, for I Know him too well.' ${ }^{47}$ This cryptic remark might allude to the fact that Winn, who passed as a white man in Natchez was actually a fellow free man of color. Winn's performance of whiteness proved to be convincing in Natchez since "he had voted and given court testimony as a white man, he had served as a road overseer, he was listed in censuses as a white man, and he had married at least one white woman." 48 In light of the mounting hostilities between them, perhaps Johnson had threatened to disclose Winn's true racial identity. Whatever 
the cause - bruised ego (surveyors established Johnson was the owner of the property in contention) or potential exposure of his true racial identity — Winn took radical action against Johnson as the case unfolded.

In 1851, Winn ambushed and murdered his old friend, after which events demonstrated just how much race mattered in antebellum Natchez. Ironically, Winn's “whiteness" protected him. Although there were witnesses who saw Winn shoot Johnson, including Johnson's son and slaves, they were unable to testify against Winn because they were people of color and he was recognized as a white man. Johnson's family and legal representatives even procured solid evidence from Winn's home state of Virginia that established him as a free man of color, but they were unable to use it in court due to a technicality. Winn was held for two years in jail and withstood three trials but ultimately the charges were dropped against him. Johnson's murder went unavenged, an outcome that underscored the protections and benefits offered to those who could pass as white. This case, as in Leiper's, reveals the delicate position that free blacks occupied in Natchez and how at times, the bonds of friendship were broken over contested issues of property and reputation. Free blacks had to be extraordinarily cautious in forming friendships. For whites, forming friendships with insincere people, meant at most hurt feelings, but for free blacks the consequences could be far more severe. ${ }^{49}$

Placing sensitive personal information in the hands of the wrong "friends" could even mean the difference between freedom and enslavement. One free woman of color, Harriet Johnson, who spent her entire childhood and adolescence enslaved, had to rely on the testimony of two white friends in court to knowingly misrepresent her racial identity so that she could avoid prosecution and possible sale. On November 8, 1859, two white men, Louis H. Corey, a Justice of the Peace and Charles M. Benbrook, served Johnson notice that as a free woman of 
color without a license to reside in Mississippi, according to state law, she had 10 days from the date of the letter to relocate. The letter was dated November 2, which meant that she had only four days to pack her belongings, sell the house that she owned, say goodbye to friends and acquaintances, collect her children, and beat a hasty retreat out of Mississippi. ${ }^{50}$

Rather than comply with this order, Johnson appeared before the Adams County Chancery Court to "pass" as white, denying that she had ever been a slave, and claiming that she was "totally free of any taint of Negro blood." As the case unfolded, witnesses testified to an invented "white" genealogy and Johnson's embodiment and performance of whiteness in Natchez. Without the protection of whiteness, she at best would have had to flee the state and lose all her property. At worst, it might have entailed witnessing her children auctioned off and she herself returned to slavery. ${ }^{51}$

The story that Johnson constructed for herself relied on the corroboration of two witnesses who undoubtedly were cognizant of her enslaved origins. One witness, Isaac Johnson, claimed to be her white cousin from Louisiana and vowed that she was the daughter of a white man, Jeremiah Johnson, and his half-Indian wife, Diana. He recalled meeting her parents when Harriet's family migrated from Virginia on their way to Missouri where Harriet Johnson purportedly grew up, although she claimed she could not recollect the name of the county. She explained that details were difficult for her to remember because her father did not provide his children with an education. She told the court, that when she was sixteen, she followed a man by the name of John Schumhon to Natchez, seduced by the promise of marriage, but was subsequently deserted by him. She then had to rely upon her own labor to support herself, but shortly thereafter, she met William Cullen who offered her a position as housekeeper and protection, "Though not hallowed by the sanction of religion.",52 
The testimony of the other witness, a local white midwife, Sarah Cecil, combined with Isaac Johnson's, was enough to convince the court of Harriet's whiteness. Cecil swore that she "never knew or heard of any one claiming the ownership of said Harriett or to exercise control over her as their property." ${ }^{53}$ Cecil testified that as a midwife, she delivered all four of Harriet and William Cullen's children and never during any of the time in which she interacted with the couple did Cullen give any indication that Harriet was his slave. Further, Cecil related that he behaved with the kindness and consideration that any husband and father would demonstrate. Finally, the fact that Harriet Johnson led a relatively quiet life free of public controversy doubtless lent credence to Cecil's statements that her disposition was one "of quiet and orderly deportment towards her neighbors, kind and benevolent to others in sickness, and well[-] disposed to all." ${ }^{54}$ Collectively, the testimony of Cecil and Johnson convinced the court that Harriet was a free white woman, wrongfully accused.

Johnson's imagined biography obscured her roots in slavery and her racial composition. In fact, William Cullen purchased and emancipated Johnson and her infant son when she was 26. She then lived with Cullen for almost 20 years, bearing and raising the couple's four children. After Cullen's death in 1841, she inherited his house and a substantial amount of money. She later became involved with another white man, Thomas Dowling, with whom she had two more children. Dowling named Johnson executor of his estate and charged her with the education of their youngest child, Annie Dowling. ${ }^{55}$ At the time of the case in 1859, she estimated her assets at $\$ 8,000$. At some point, Johnson slipped over the color line. She appears in the 1850 census as a white woman, and all her children were listed as white as well. If not for this incident when Corey and Benbrook recognized her as an unlicensed free woman of color and she almost lost her freedom, she might have continued passing as white undetected. Nevertheless, thanks to her 
friends' testimony, she prevailed in the case and was found to be white, thus escaping slavery as well as the dissolution of her family and property. ${ }^{56}$ Unlike the cases of Fanny Leiper and William Johnson, Harriet Johnson's friends proved that they could be trusted with critical personal information and remain true to the ideals of comradery and the mutual obligations of friendship.

In spite of the many risks of living in a society where freedom was predicated upon whiteness, friendships overwhelmingly enriched the lives of free people of color in Natchez and served a larger purpose. Friends confided in one another about intimate details of their health, marriage, and hopes for the future and enjoyed gender-specific activities together. Free men of color wove homosocial bonds of friendship with one another and went to the horse races, hunted, played cards and drank together into the wee hours of the night, and defended each other in fist fights. Free black women sewed together, exchanged information about child birth, breastfeeding, and running households, and socialized within one another's homes. Aside from these commonplace components, friendships also had a utilitarian feature in that they often were integral to the efforts of black people to acquire and retain freedom. By necessity, then, free men and women of color and their families regularly made it a practice to build networks of friendly patronage with former owners in addition to other local whites to ensure their safety and prosperity and entrust them with protecting family members' financial and legal interests in Natchez. On occasion, these friendly patron/client relationships blossomed into full-blown friendships that seemed, on their face, to transcend the racial realities of the time period but likely remained constrained.

Friendships among other free people of color and quite regularly between extended family members were ideal for issues of trust and security. Men and women who navigated the 
high stakes of the uncertain racial climate in Natchez and elsewhere in the Deep South found comfort in those who shared the same status and even the same bloodlines. Even when they migrated out of Natchez, they maintained their connections and worked hard to sustain their friendships with one another, communicating by letter and word of mouth or traveling back to Natchez for visits. No doubt many shared the sentiment of free woman Victoir Brustie, a friend of the Johnson women, who reminded them to pass on her wishes to all other family members and servants and "'Tell them that my dayly thoughts are with them as though I was amidst them all. $^{57}$

\footnotetext{
${ }^{1}$ I would like to thank the following people for their patience, assistance, and solid advice during the writing of this manuscript: Jen Barclay, Daina Ramey Berry, Cassandra Good, Sakina Hughes, Janet Moore Lindman, Abu Towghi, Warren Milteer, and the anonymous reviewers. All of their comments and suggestions made this a stronger article and for that, I am so grateful. Quote from Virginia Meacham Gould, Chained to the Rock of Adversity: To be Free, Black, \& Female in the Old South (Athens, 1998), 23.

${ }^{2}$ Gould, 18 .

${ }^{3}$ Historical Census Browser. Retrieved [July 10, 2010], from the University of Virginia, Geospatial and Statistical Data Center: http://fisher.lib.virginia.edu/collections/stats/histcensus/index.html. In order to fully facilitate my analysis of free people of color living in Natchez, I created a database of the roughly nine hundred free people of color who resided at some point in Natchez between the years 1779-1865, which I named The Ribianszky Database of Free People of Color. The categories of analysis that have been created to flesh out their lives in the maximum detail include: age, color, property ownership, slave-holding, children, relationship status, year emancipated, year of migration to Natchez, previous owner's name, indenture, apprenticeship, and any incidence of violence that was recorded or implied in the documentation available. Within this last category of violence, I have further refined it to include if they themselves experienced the following: born enslaved, raped and/or sexually exploited, became/were slaveholders, threatened with and/or deportment, re-enslavement, imprisonment, whipping and/or other physical assault, murder, domestic abuse, wrongfully accused of a crime, association with violence (i.e. the murder or other violence of a family member or close friend), enslavement of child, and other threats to their bodily or emotional health.
}

${ }^{4}$ There is a rich body of work on community and friendship networks that harken back to some of the "classic" studies by: Eugene Genovese, Roll, Jordan, Roll: The World the Slaves Made (New York, 1974); Herbert Gutman, The Black Family in Slavery and Freedom, 1750-1925 (New York, 1976); Sidney W. Mintz and Richard Price, The Birth of African American Culture: An Anthropological Perspective (Boston, 1992, originally published in 1976); Leslie Howard Owens, This Species of Property: Slave Life and Culture in the Old South (New York, 1976); Lawrence Levine, Black Culture and Black Consciousness (New York, 1977); John W. Blassingame, The Slave Community (1972 reprint, New York, 1979); Sterling Stuckey, Slave Culture: Nationalist Theory and the Foundations of Black America (Oxford, 1987); Brenda E. Stevenson, Life in Black \& White: Family and Community in the Slave South (New York, 1996); and Daina Ramey Berry, Swing the Sickle for the Harvest is Ripe: Gender and Slavery in Antebellum Georgia (Champaign, IL, 2007) to mention a short list of critical ones. The two aforementioned studies on gendered friendships among the enslaved are Deborah Gray White, Ar'n't J a Woman? Female Slaves in the Plantation South (New York, 1985) 119-141. Sergio Lussana points out that activities such as drinking, gambling and wrestling offered enslaved men an opportunity to form "an all-male subculture through 
which they constructed their own independent notions of masculinity, friendship, solidarity, and resistance." in "No Band of Brothers Could Be More Loving": Enslaved Male Homosociality, Friendship, and Resistance in the Antebellum American South," Journal of Social History 46 (2013): 872.

${ }^{5}$ Approximately 200 free black people in Natchez were associated with slave ownership in their households from 1779-1865 according to data that I assembled in my dissertation research (refer to footnote 3 ).

${ }^{6}$ I have been fortunate to be able to draw on a rich historiographical body on free blacks and free people of color, both terms I use synonymously within this article. A very short list of some of the important monographs focusing on the South and dating back to the early part of the 20th century are: Carter G. Woodson, Free Negro Owners of Slaves in the United States in 1830; Together With Absentee Ownership of Slaves in the United States in 1830 (Washington, D.C, 1924) and his Free Negro Heads of Families in the United States in 1830 Together With a Brief Treatment of the Free Negro (Washington, D.C, 1925); John Hope Franklin, The Free Negro in North Carolina, 1790-1860 (Chapel Hill, 1943); Ira Berlin, Slaves Without Masters: The Free Negro in the Antebellum South (New York, 1971); H.E. Sterkx, The Free Negro in Ante-Bellum Louisiana (Cranbury, 1972); Marina Wikramamayake, A World of Shadow: The Free Blacks in Antebellum South Carolina (Columbia, 1973); Gary B. Mills, The Forgotten People: Cane River's Creoles of Color (Baton Rouge, 1977); Michael P. Johnson, and James L. Roark, Black Masters: A Free Family of Color in the Old South (New York City, 1984); Johnson and Roark, No Chariot Let Down: Charleston's Free People of Color On the Eve of the Civil War (Chapel Hill, 1984); Larry Koger, Black Slaveholders: Free Black Slave Masters in South Carolina, 1790-1860 (Jefferson, N.C., 1985); Orville Vernon Burton, In My Father's House Are Many Mansions: Family and Community in Edgefield, South Carolina (Chapel Hill, 1995); Kimberly Hanger, Bounded Lives, Bounded Places: Free Black Society in Colonial New Orleans, 17691803 (Durham, 1997); Sybil Kein, Creole: The History and Legacy of Louisiana's Free People of Color (Baton Rouge, 2000); Judith Kelleher Schafer, Becoming Free, Remaining Free: Manumission and Enslavement in New Orleans, 1846-1862 (Baton Rouge, 2003); Wilma King, The Essence of Liberty: Free Black Women During the Slave Era (Columbia, MO, 2006); Amrita Chakrabarti. Myers, Forging Freedom: Black Women and the Pursuit of Liberty in Antebellum Charleston. (Chapel Hill, 2011); and Emily Clark, The Strange History of the American Quadroon Free Women of Color in the Revolutionary Atlantic World (Chapel Hill, 2013) to name just a few. Many of these studies showcase some of the characteristics of friendship between free people of color, the enslaved, and whites that I have found in Natchez.

${ }^{7}$ A number of works have addressed the interlocking dynamics of friendship and patronage between individuals of differing socioeconomic status. Even among well-meaning white abolitionists in the North, friendships between themselves and black people were not friction-free. See for example, Margaret Hope Bacon, "The Motts and the Purvises: A Study in Interracial Friendship," Quaker History 92 (2003): 1-18. Historian Allan Silver commented on the broad range of the word friendship. He noted, "By the 18th century, however, the meaning of friendship encompassed both older and modern meanings. The word 'could mean a distant or close relation, a patron or a client, an individual to whom one was tied by mutual sponsorship, or someone attached by warm affection' in Allan Silver, "Friendship in Commercial Society: Eighteenth-Century Social Theory and Modern Sociology," American Journal of Sociology 95 (1990): 1487. Another work that tackles the relationship between friendship and patronage is Naomi Tadmor's Family and Friends in Eighteenth-Century England: Household, Kinship, and Patronage (Cambridge, 2001).

${ }^{8}$ My work acknowledges this instability by putting forth the notion of generational freedom, in which I distinguish with those who were born into slavery but later freed, the foundational generation, which could also include parents and their children, as well as grandchildren. I name the generations that follow the foundational generation the conditional generations--those who were born free but whose continued freedom was based upon not only their compliance of a demanding and often unfair system, but their persistence within the vagaries of an ambiguous and often arbitrary freedom that was not permanently guaranteed. In the conceptualization of this, I am deeply indebted to Ira Berlin's ideas on the differing experiences of the enslaved, from the first generation that he terms charter generation to the subsequent plantation generation in Many Thousands Gone: The First Two Centuries of Slavery in North America (Harvard, 1998), 12-13.

${ }^{9}$ The sources examined for this research include Adams County chancery, circuit, and probate court records, Mississippi state court records, personal letters, wills, deeds, newspapers, Spanish colonial papers, tax records, census data, police records, among other documentation. Family papers, particularly the very rich Johnson 
collection - which contain the letters that were written between Ann Johnson and her husband William's family who lived in New Orleans as well as the diary William kept faithfully for 15 years - help reconstruct a multifaceted account of friendship among a group of people who as a whole, did not leave a voluminous personal record.

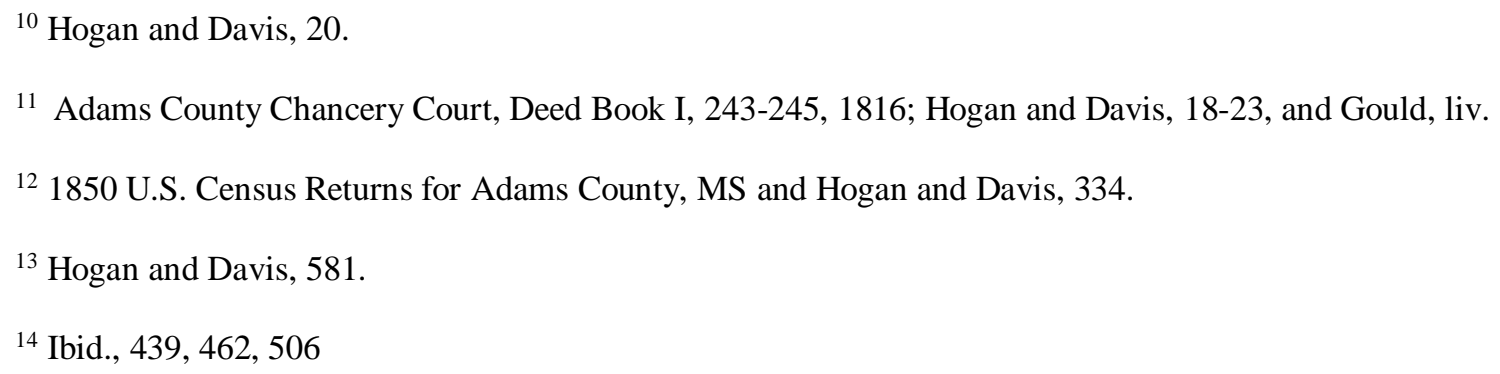
Rosenberg, "The Female World of Love and Ritual: Relations between Women in Nineteenth-Century America," Signs 1 (1975): 11-13 and Joan R. Gundersen, "Kith and Kin: Women's Networks in Colonial Virginia," in The Devil's Lane: Sex and Race in the Early South, ed. Catherine Clinton and Michele Gillespie (New York, 1997), 9496.

16 The letters that traveled between Natchez and New Orleans from Ann Johnson and her daughters to Adelia Miller and her daughters focus on the produce, toiletries, fabrics and other items that they shipped to each other as well as stories about parties, childcare, and other free people of color in both communities. See Gould.

${ }^{17}$ Hogan and Davis, 462

18 Gould, 29.

${ }^{19}$ Gould, 29.

${ }^{20}$ For a smattering of these types of activities, see Hogan and Davis 46, 520, 578, and 581.

${ }^{21}$ Hogan and Davis, 360.

22 Johnson makes mention of several occasions for which both he and McCary called on doctors for house calls to attend their sick children. See Hogan and Davis, 102, 360, and 520.

${ }^{23}$ Hogan and Davis, 370.

${ }^{24}$ The account of Kitty McCary was recorded in Johnson's diary in Hogan and Davis, 146. He noted other incidents of violence toward free people of color but aside from writing them, there is little sense that the community of free blacks could substantively protest openly without bringing down the wrath of the white community. For example, in 1836, Johnson relayed that, "The Gard [sic] took Nancy Latimore and Cut her all over her Back, whiped [sic] her very much. She went through the Market the next morning with her clothes hanging all off at Each Shoulder. Her back was very much whipped. It was thought Dr. Lattimore make [sic] her walk in the Streets that way." Lattimore was a free woman of color, licensed to remain in the state in 1832 as shown in Adams County Court and Police Board Minutes, 1832-45, March, 1832; Adams County Deed Records, CC, 46.

\footnotetext{
${ }^{25}$ Hogan and Davis, 99.

${ }^{26}$ Hogan and Davis 27-29, 603 and Gould, 11.

${ }^{27}$ Adams County Chancery Court, Will Book 2, 229-230; Hogan and Davis, 368.
} 
${ }^{28}$ Hutchinson, A. Code of Mississippi: Being an Analytical Compilation of the Public and General Statutes of the Territory and State, with Tabular References to the Local and Private Acts, from 1798-1848, with the National and State Constitutions, Cessions by the Choctaw, 303.

${ }^{29}$ Ibid, Richard Morris, “The Course of Peonage in a Slave State,” Political Science Quarterly 65 (1950): 244.

${ }^{30}$ For a discussion of these efforts to link themselves with the Catholic Church by baptism strategies or membership in religious brotherhoods across Latin America, see such studies as: Ronald L.F. Davis, The Black Experience in Natchez, 1720-1880 (Denver, 1999),112-115; Mary C. Karasch, "Free Women of Color in Central Brazil, 17791832," in David Barry Gaspar and Darlene Clark Hine, eds. Beyond Bondage: Free Women of Color in the Americas (Urbana, 2004), 258-266; David Wheat, "My Friend Nicolas Mongoula: Africans, Indians, and Cultural Exchange in Eighteenth-Century Mobile," in Richmond F. Brown, ed. Coastal Encounters: The Transformation of the Gulf South in the Eighteenth Century (Lincoln, NE, 2007), 126-131, and Emily Clark, Masterless Mistresses: The New Orleans Ursulines and the Development of a New World Society, 1727-1834 (Chapel Hill, 2007). All of the Johnson children's baptism certificates were duly recorded at the cathedral with the exception of one of their children who died shortly after birth, Hogan and Davis, 379.

${ }^{31}$ Adams County Chancery Court, Deed Book BB, 1830, 211; 1860 Adams County Census; and Davis, 112-116.

${ }^{32}$ Gould, 16.

${ }^{33}$ Adams County Chancery Court, Deed Book D, 36-7, 1805.

${ }^{34}$ Hutchinson, 524-525, 533. The 1831 law coincided with Nat Turner's rebellion in Virginia and resulted in limitations upon the number and activities of free blacks, including raising the price of their annual license renewals from $\$ 1$ to $\$ 3$.

${ }^{35}$ The vigilance committee in Natchez investigated a number of free people of color to ensure their compliance with Mississippi's 1831 legislation requiring them to legally register with county courts. The fresh hysteria in 1841 regarding free blacks and their real or imagined collusion with abolitionists precipitated into their impromptu trials before the committee and a number of individuals were ordered to leave Mississippi. Some men, women, and children were unlucky in this pursuit and were deported from the state. Others, like free woman of color, Lavinia Bird, met an even more harsh fate. She was persecuted as a free woman of color who had lived illegally in Natchez, jailed, and sold for a period of five years. See Charles Sydnor, "The Free Negro in Mississippi Before the Civil War," American Historical Review 32 (1927), 449; Gould, xxvii, xxx; Adams County Census Returns, 1840; Adams County Chancery Court, Police Board Records, 1841; Hogan and Davis, 341-346; Joyce Broussard, "Stepping Lively in Place: The Free Black Women of Antebellum Natchez" in Mississippi Women: Their Histories, Their Lives - Volume 2, eds. Elizabeth Anne Payne, Martha H. Swain, and Marjorie Julian Spruill (Athens, 2010), 31-32; The State vs Holdon, John \& Carter, Eliza, Historic Natchez Foundation, Adams Circuit Court, Box 3, Drawer 182, New Box 15-24, 1832; and The Natchez Courier, Saturday, August 01, 1840, Issue 222, col A.

${ }^{36}$ Hogan and Davis, 12.

${ }^{37}$ John Hebron Moore, The Emergence of the Cotton Kingdom in the Old Southwest: Mississippi, 1770-1860 (Baton Rouge, 1988), 265-6; Hogan and Davis, 12-13, 53.

${ }^{38}$ Gould, 43.

39 Nik Ribianszky, "'She Appeared to be Mistress of Her Own Actions, Free From the Control of Anyone:"” Property Holding Free Women of Color in Natchez, Mississippi, 1779-1865" (Thesis, Michigan State University, 2003); Adams County Chancery Court, Deed Book DD, 1842, 465-466; Adams County Chancery Court, Police Board Records, 1844, 448; Hogan and Davis, 597; Adams County Chancery Court, Will book 4,1869, 576; Cecilia M. Shulman, "The Bingamans of Natchez," The Journal of Mississippi History LXIII (2001): 301, 310-312.

40 At least one of Harriet Johnson's daughters, Mary A. Cullen Cross, married a white man. It is unclear if Annie Celine Dowling married before her death in 1873 at the age of 26. See Adams County Chancery Court, Will Book 3 , 
1855, 35-37 and Thomas Reber v. Thomas J. Dowling et al. and Thomas J. Dowling et al. v. Thomas Reber Supreme Court of Mississippi, 65 Miss. 259; 3 So. 654, 1887.

${ }^{41}$ The Barland daughters married as follows: Adams County Chancery Court, Marriage Records, William Henderson and Margaret Barland, 1808; Asa German and Elizabeth Barland, 1808; Martin Thomas and Betsey [Agnes] Barland, 1809; and Wilson B. Harper \& Susannah Barland, 1819. George Winn's daughters, Polly [also called Mary] married a white overseer William Mosbey in 1834 or 1835 and Helen later married Washington Ford. See the footnote in Hogan and Davis, 209.

${ }^{42}$ Joseph Barksdale, Appellant, v. George B. Elam et al., Appellees. Supreme Court of Mississippi, 30 Miss. 694, 1856.

${ }^{43}$ It is also likely that some daughters of the Fitzgerald clan married white men as well. These free families of color were actually the result of the relationships between two Scottish brothers, James and George, and their enslaved women, Betsy and Mary. George and Mary, who was Jamaican, had five daughters and two sons. Besides freedom, George left nothing in his will to his children or their mother. His brother, James, however, in addition to emancipating his three children and making provisions for their education and vocation, left them property as well. He also left Betsy property as well. Personal conversations while conducting research in the Chancery Court with a long-time Natchez resident indicates that part of the Fitzgerald family considers themselves white while some identify as black. This suggests that some daughters - or perhaps sons - married white partners. See Adams County Chancery Court, Deed Book D, 1804, 478-9; Adams County Chancery Court, George Fitzgerald's Will, Will Book 1, 1808, 37; and Adams County Chancery Court, James Fitzgerald's Will, Will Book 1, 1816, 165.

${ }^{44}$ Apparently, there is some contestation over whether Malvina Huffman was a free woman of color or whether she was a white woman. As I have seen documents describing her as both, I will, for the sake of continuity with my other scholarship, maintain she was a free black woman but open the possibility, as so many others in the Lower South, including Natchez, that she was passing as white in some situations. See Joyce L. Broussard, "Malvina Matthews: The Murderess Madam of Civil War-Era Natchez," The Journal of Mississippi History LXXIII (2011): 44.

${ }^{45}$ Bill of Complaint by Fanny Leiper, December 2, 1847, Leiper vs. Huffman.

${ }^{46}$ Leiper vs. Huffman. et al, Mississippi High Court of Error and Appeals case 6185, (1851).

${ }^{47}$ Hogan and Davis, 57.

${ }^{48}$ Hogan and Davis, 61.

${ }^{49}$ Hogan and Davis, 58-62.

${ }^{50}$ Harriett Johnson vs. L.H. Corey and L.M. Benbrook, Adams County, MS, Chancery Court Case No. 107, Box No. $11,1860$.

${ }^{51}$ I was very fortunate during some unrelated research in Natchez to have stumbled across this document in the archives. My understanding of Harriet was as a free, propertied woman of color up to that point in time. But after reading through this particular court case, I decided to investigate further and after some searching through deed books, found her original bill of sale and emancipation document, substantiating without a shadow of a doubt that Harriet Johnson had been at one, enslaved.

${ }^{52}$ Harriett Johnson vs. L.H. Corey and L.M. Benbrook.

${ }^{53}$ Ibid.

${ }^{54}$ Harriett Johnson vs. L.H. Corey and L.M. Benbrook. 
${ }^{55}$ Will of Thomas Dowling, Adams County Chancery Court, Will Book 3, 1855, 35-37.

561850 U.S. Census Returns for Adams County, MS; Harriett Johnson vs. L.H. Corey and L.M. Benbrook.

${ }^{57}$ Gould, 23. 